TEME, г. XLI, бр. 4, октобар - децембар 2017, стр. 855-872

Прегледни рад

DOI: $10.22190 /$ TEME1704855S

Примљено: 5. 5. 2017.

UDK 005:37

Ревидирана верзија: 6. 11. 2017.

$37: 339.187 .44$

Одобрено за штампу: 15. 11. 2017.

\title{
EDUCATIONAL FRANCHISING AS A STRATEGY FOR INTERNATIONALIZATION OF EDUCATION
}

\author{
Suzana Stefanović ${ }^{1 *}$, Milica Stanković ${ }^{2}$ \\ ${ }^{1}$ University of Niš, Faculty of Economics, Niš, Serbia \\ ${ }^{2}$ Higher School of Applied Professional Studies, Vranje, Serbia \\ *suzana.stefanovic@eknfak.ni.ac.rs
}

\begin{abstract}
The education becomes a necessity, rather than an option. In addition, the competition in the knowledge and education market is increasingly stronger. In this respect, educational institutions begin to operate as entrepreneurial organizations, with a strong tendency towards the internationalization of their business activities. Educational franchises become global trend, bearing in mind that they are focused not only on achieving business goals, but also on achieving social goals, such as education and dissemination of knowledge. Despite numerous literature about franchising, the field of educational franchising is still insufficiently researched. The aim of the paper is to point out the importance of educational franchising and its role in the internationalization of education, both in the sector of formal and in the sector of nonformal education, and to determine the influence of internal factors from the domain of age, size and areas of providing educational services on the internationalization of educational franchises.
\end{abstract}

Key words: educational franchising, internationalization, internal factors, franchisee, franchisor.

\section{ЕДУКАТИВНИ ФРАНШИЗИНГ КАО СТРАТЕГИЈА ИНТЕРНАЦИОНАЛИЗАЦИЈЕ ОБРАЗОВАЫА}

\footnotetext{
Апстракт

Образовање све више постаје нужност уместо избора. Уз то, све се више заоштрава конкуренција и на тржишту знања и образовања. У том смислу, образовне институције почињу да функционишу као предузетничке организације, уз наглашену тенденцију ка интернационализацији пословних активности. Едукативне франшизе постају глобални тренд, имајући у виду да су усмерене не само на остварење профитних циљева већ и друштвених циљева као што су образовање и ширење знања. Упркос бројној литератури на тему франшизинга, едукативни франшизинг је још увек недовољно истражена област. Циљ рада је да се укаже на значај едукативног франшизинга и његову улогу у интернационализацији образовања, како у сектору формалног тако и у сектору нефор-
} 
малног образовања, те да се утврди утицај унутрашњих фактора из домена старости, величине и области пословања на интернационализацију едукативних франшиза.

Кључне речи: едукативни франшизинг, интернационализација, интерни фактори, корисник франшизе, давалац франшизе.

\section{INTRODUCTION}

Contemporary business conditions impose the need for internationalization in the field of education. Actually, educational institutions begin to operate as entrepreneurial organizations, while knowledge is observed as any other goods that is the subject of exchange on the market, in this case, on the knowledge market. International education is closely related to franchising, while educational franchises are becoming a global trend. Despite the extensive literature on the subject of franchising, there are still not enough studies about educational franchising. Therefore, the aim of this paper is to point out the importance of educational franchising and its role in the internationalization of education (both in the sector of formal and in the sector of non-formal education), and to determine the influence of internal factors from the domain of age, size and areas of providing educational services on the internationalization of educational franchises.

In this paper, we will try to prove the hypothesis that the size of an educational franchise system has a positive impact on internationalization, namely that there is a strong and statistically significant positive correlation between the size and the internationalization of an educational franchise system. In addition, the other hypothesis is that the age of educational franchise system positively affects the internationalization, namely that there is a strong and statistically significant positive correlation between the age and the internationalization of the educational franchise systems. The size of an educational franchise system is observed through the total number of franchise units, while the age of an educational franchise is observed through the number of years in franchise business. Another assumption is that the area of providing educational services affects the internationalization, namely, there is a difference in the internationalization of educational franchise systems in various fields of educational services.

The study is designed in a manner that in the first part of the study we explain the concept, and we point out the importance of educational franchising as a strategy for the internationalization of educational institutions. The second part of the paper deals with the concept of nonformal ie. non-academic educational franchising, while explains concepts of "shadow education" and learning centers, and indicates the differences between them in order to to show the importance of educational franchises 
in the internationalization of the non-formal education programs. In the third part of the paper, we indicate the impact of internal factors (from the domain of the size, age and areas of providing educational services) on the internationalization of educational franchising systems. In fact, the third part of the paper focuses on the correlation analysis between the size of the educational franchise system and the number of international franchise units, as well as the correlation analysis between the age of the educational franchise system and the number of international franchise units. In addition, we will analyze whether there is a difference in internationalization between the educational franchises from different areas of providing educational services.

\section{EDUCATIONAL FRANCHISING - \\ STRATEGY FOR INTERNATIONALIZATION OF EDUCATION}

In terms of globalization, educational franchises become a growing phenomenon (Altbach, 2012). Actually, due to the development of modern information and communication technologies and the increasing interconnectedness of the world economy, education begins to follow the conventional path of internationalization, as well as enterprises (Altbach, 2002; Hira, 2003). Education and knowledge become the goods that are the subjects of the international trade. In order to build a set of required skills, consumers 'buy' education and knowledge from the multinational corporations or academic institutions that operate as entrepreneurial organizations (Altbach, 2002). The term internationalization of education is often used to describe one or a combination of the following activities: international mobility of students and teaching staff between countries, internationalization of the curriculum of higher education, international connection of research and open learning programs, bilateral, regional and international recognition of higher education qualifications (Herman, 2004). However, the internationalization of education is not simple, given that the topics that are relevant for students in one country may be irrelevant for students in another country. Also, it is very difficult to control the key elements of the curriculum and pedagogical philosophy (Altbach, 2002). Because of this, franchising can be seen as a response to the challenges in internationalization of education.

International education (or transnational education) is often associated with educational institutions and programs franchising. Educational franchising is similar to the business franchising, although it has its own specificities. The literature does not pay so much attention to the educational franchising as to the business franchising (Yorke, 1993). Characteristics of business format franchising, referring also to the educational franchises are as follows (Adams \& Prichard Jones, 1990): franchisor has a markettested product or service (in this case an academic or tutoring program), 
franchisee operates under the franchisor's brand, franchisee operates in accordance with the franchisor's standards, and franchisee pays a fee to the franchisor.

Educational franchises are an excellent method for starting a successful business along with provision of assistance to young people in order to make changes in their lives. As education becomes a necessity rather than an option, educational franchises gain more importance. Educational franchises include the provision of services to students of all ages, starting from educational services for children (education through entertainment), to tutoring and preparation for tests as well as business training. Some of the educational franchises can be run from home, while other, such as centers of learning, require renting an appropriate place for providing the tutoring services. With annual revenue of $\$ 40$ billion, the sector of education franchises is a mature sector with the ability to motivate entrepreneurs to invest. It is expected that educational franchises will grow at a rate of 5\% annually over the next 5 years (Franchise help, 2016).

The franchising in education appears most often in the form of academic franchising ie. franchising in the sector of formal education (franchising programs at the undergraduate, master and doctoral studies), and franchising in the sector of non-formal education (tutoring and supplementary education of children and adults of all ages). The key difference between the academic and non-formal educational franchising is that academic institutions sell franchises of academic programs, while organizations of non-formal education sell franchises of tutoring and supplementary education programs. Given that the data from empirical research are related to organizations of non-formal education engaged in franchising, the paper will focus on that type of educational franchising. The aspect of academic franchising will be elaborated in more detail in a future research.

\section{FRANCHISING IN THE SECTOR OF NON-FORMAL EDUCATION: FROM "SHADOW EDUCATION" TO LEARNING CENTERS}

Franchising in the sector of non-formal education is considered as a form of supplemental education and can appear in different forms. One form of educational franchising in the sector of non-formal education includes individual lessons which are held by tutors in their homes. Alternatively, group classes or online classes can be organized (Bray \& Lykins, 2012, p. 1). Unlike traditional education, which is considered a tool for equalizing children from different social classes in education, this supplemental education can deepen the educational gap between them. This, in particular, bearing in mind that richer families can provide supplemental education for their children, while poorer families are not in a position to do so (Southgate, 2009). Moreover, tutoring can lead to 
inefficiencies in the education system. The situation in which teachers do not make enough efforts in their regular classes in order to save energy for private tutoring classes is particularly problematic (Bray \& Lykins, 2012, p. 1). However, an increasing number of families point out that regular schools do not comply with their expectations, so private supplemental tutoring exceeds the educational gap and promote and maintain a competitive advantage for their children (Bray \& Lykins, 2012, p. 1). Essentially, there are two key factors which encourage the development of tutoring and supplemental education. First, studies have shown that an increasing number of parents have a proactive attitude towards their children's education (Davies, Aurin \& Quirke, 2002; Lareau, 2002). Second, an increasing number of children decide to study, so parents believe that they can be better prepared for college by using supplemental education (Aurin \& Davies, 2004).

If we analyze European countries, there are high rates of tutoring in the South Europe, starting from Greece and Cyprus. In Eastern Europe, the growth of tutoring is also noticeable, especially in the former Soviet Republics, where the key driver of this phenomenon was the reduction of teachers' salaries, which led to the fact that they look for additional sources of income (European Commission, 2011, p. 24). In Lithuania, 62\% of the interviewed university students have pointed out that they attended additional classes during the last year of high school. In Slovakia, 56\% of students indicated that they had private tutoring. Also, there is a long tradition of private tutoring in Western Europe. In Austria, around 20\% of parents pay an additional tutoring for their children (European Commission, 2011, p. 13). In Northern Europe, private tutoring is the least represented, given that in the Scandinavian countries, students have additional classes within the formal public education. Certainly, there may be differences among countries in the same part of Europe, but also within a single country, particularly when it comes to comparisons between rural and urban areas. Tutoring is more prevalent in urban areas. For example, in Romania, 27\% of children in urban areas had private tutoring compared with only $7 \%$ in rural areas (European Commission, 2011, p. 25). In Japan, case studies have shown that students use their free time for additional classes, due to the fact that they compete with other students in a very selective education system in order to manage to enroll in prestigious universities (Southgate, 2009). From the students who study at prestigious universities, more than $60 \%$ participated in the "shadow education" for a year after high school. Attending a prestigious university largely determines the possibility for employment (Southgate, 2009).

"Shadow education" is a form of tutoring, which is a global phenomenon (Mori \& Baker, 2010). This concept follows the curriculum of the public school system and usually includes support of individual tutors for doing homework and preparation for tests (Stevenson \& Baker, 1992; Bray, 1999; Baker et al., 2001). Stevenson and Baker (1992) have established the 
term "shadow education", by which they wanted to emphasize that this kind of education follows the formal education as a shadow, in terms of curricula and exams, but remains virtually unnoticed. "Shadow education" still receives little attention by researchers and authors and a very small number of studies deals with the analysis of this concept of education (Southgate, 2009). The use of "shadow education" varies, but even in countries where it is used the least, about $20 \%$ of students pointed out that they had additional classes during their education (Baker et al., 2001). The phenomenon of "shadow education" appears more and more in Europe (European Commission, 2011, p. 17). For example, Murawska and Putkiewicz (2006) investigated 849 students at the first year of studies in 2004/05 in Poland, and $49.8 \%$ of them emphasized that they have had private lessons.

While "shadow education" continues to gain the importance, there is also a new kind of non-academic educational franchising in the form of learning centers that offer a variety of educational services. Learning centers are educational centers that encourage learning and strengthen students skills. In learning centers, students can acquire both general education and education in specific areas of interest. In addition, teachers provide comprehensive support to their students in learning. The educational materials for students, both printed as well as electronic, are available in learning centers. These educational materials encourage autonomy in learning (OnHand Schools, 2016). Franchising is a very suitable model for learning centers, due to the fact that it offers centralized control of the creation and delivery of educational services, while giving individual franchisees the freedom to adapt services to local needs. In fact, franchising makes tutoring become a much more entrepreneurial-oriented area, with long-term goals. The experience in the field of education is not necessary for buying tutoring franchise, because franchisees should not be educators and teachers, but managers. In fact, teachers are considered as undesirable franchisees, because they lack the entrepreneurial spirit. Learning centers' franchises develop their own curriculum and evaluation, rather than taking them from the regular education system, as in the case of "shadow education". Based on the knowledge assessment test, these franchises distribute students in the program regardless of the learning material in their schools.

Learning centers usually have "education director" and "business director". "Education director" is intermediary among parents, tutors and students and he/she is often responsible for ensuring the integrity of the implemented program. "Business director" is responsible for the administrative aspects of running a business, including the budget, promotion and recruitment. Education director is usually set by the franchisor, given that he/she is responsible for guaranteeing the quality of education and the preparation of regular periodic reports that are sent to the franchisor. On the other side, business director should be a connoisseur of the local market, and 
he/she is usually employed by the franchisee, but with the franchisor's approval (Aurin, 2006). "Shadow education" and learning centers are different in many aspects, but the following key differences that support the fact that learning centers are more suitable for franchise business have been stressed (Aurin \& Davies, 2004):

1) Short-term versus long-term goals. In essence, the "shadow education" is focused on the immediate, short-term goals. "Shadow education" is oriented on specific goals and objectives: student should pass the upcoming test or achieve higher scores on the exam. In contrast, learning centers spread "skill building" learning model. In essence, learning centers offer a full complement of regular schools in comparison to "shadow education".

2) Development of independent curriculum. "Shadow education" typically uses school material (notebooks, books and tests) that students receive in formal schools. In contrast, learning centers develop their curricula, textbooks and knowledge tests.

3) Expanded services. Individual "shadow educators" are specialized in certain areas and they work with a limited number of students. In contrast, learning centers offer a wide range of services for students of different ages, from pre-school to adult education and training courses for requalification.

4) Investments and infrastructure. "Shadow educators" enter and exit the educational market with little or no investment. Their business is based on recommendations from a friend, family member or current or former students. In contrast, learning centers attract individual entrepreneurs who expect a full-time job from which they will be able to support themselves in the coming years. The initial investment for learning centers franchises is about $\$ 50,000$ up to 75,000 , depending on the franchise.

\section{METHODOLOGY}

Educational franchising increasingly gains importance, especially because it contributes to the dissemination of knowledge and access to education. However, this is still an insufficiently researched area. In this regard, the paper is devoted to the analysis of the franchise concept in the sector of education and factors that affect the internationalization of educational franchises. The aim is to highlight the relationship between the franchise systems' size, ages and areas of providing educational services and their tendency towards the internationalization. The paper starts from the following hypotheses:

H1: The size of the educational franchise system has a positive statistically significant impact on the franchise system internationalization. 
H2: The age of the educational franchise system has a positive statistically significant impact on the franchise system internationalization.

H3: The educational franchise system's area of providing educational services has an impact on the franchise system internationalization.

The empirical research is conducted by using secondary data obtained on the basis of a list of global franchises that are ranked each year on the website of Entrepreneur magazine. On the list of Entrepreneur magazine for the year 2015 there are even 72 franchises in the field of education, pointing to the importance of educational franchise globally (Entrepreneur, 2015). For each of these educational franchises the database contains information relating to the educational franchise systems' size, age, internationalization, area of providing educational services and also information about the amount of necessary investments, initial fees and royalties, as well as data on the duration of the franchise agreement. The analysis of empirical research results is conducted by using a SPSS Statistics 20 software package. The statistical techniques used in the paper are correlation analysis and Kruskal Wallis test. Correlation analysis examines whether there is a link between certain variables, as well as the direction and strength of these relationships. We used Kruskal Wallis test to determine differences in preferences towards internationalization between educational franchise systems from various areas of providing educational services.

\section{RESULTS AND DISCUSSION}

Despite the fact that the interest for franchising grows and the importance of franchising in education is noticed, there is still a small number of studies that analyzes educational franchises. Even fewer studies have been devoted to the educational franchises internationalization. Therefore, the paper focuses on the educational franchises internationalization in order to highlight the importance of franchising in the education sector and the possibility of franchising systems' international expansion. Considering the fact that the possibility of franchising system's internationalization is influenced by numerous factors, both internal (factors from the domain of franchise system's internal characteristics) and external factors (factors from the franchise system's external environment), the aim of this study is to determine the relationship between internal factors and the internationalization of educational franchises.

There are 72 educational franchises on the list of franchises on Entrepreneur magazine's website. There are even 20 educational franchises on the list of Top 500 Franchise in 2015 (Entrepreneur, 2015). This means that educational franchises account for $4 \%$ of total franchises ranked on the Top 500 Franchise list for 2015. If we consider that franchises on this list are classified into 17 categories (education, automotive, business services, 
children's products \& services, financial services, food, health care, home improvement, hotels \& motels, maintenance, personal-care businesses, pet businesses, recreation, retail, service businesses, tech businesses, training), and that the franchising sector in education is one of the latest trends in modern business conditions, we can conclude that its importance is recognized globally. Table 1 shows a list of educational franchises that are ranked on the list of Top 500 Franchise for 2015.

Table 1. Educational franchises which are ranked on the list of Top 500

Franchise for the year 2015

\begin{tabular}{lc}
\hline Education franchise & Franchise 500 - Rank \\
\hline Kumon Math \& Reading Centers & 20 \\
Eye Level Learning Centers & 68 \\
Mathnasium Learning Centers & 86 \\
Club Z! In Home Tutoring Services & 116 \\
Tutor Doctor & 156 \\
High Touch- High Tech & 183 \\
Sandler Training & 189 \\
JEI Learning Centers & 198 \\
School of Rock & 205 \\
Dale Carnegie Training & 228 \\
LearningRx & 268 \\
Huntington Learning Centers & 301 \\
Young Rembrandts Franchise Inc. & 312 \\
KidzArt & 320 \\
The Little Gym & 366 \\
Above Grade Level In-Home Tutoring & 398 \\
Engineering for Kids & 409 \\
Mad Science Group Inc. & 471 \\
Drama Kids Int'l. Inc. & 479 \\
Abrakadoodle & 498 \\
\hline
\end{tabular}

Source: Adapted by the authors based on data from the Entrepreneur magazine website

Although the oldest educational franchise is expanding through its franchise units for 58 years, almost half of educational franchise began its franchise business after 2009 , more precisely $43 \%$ of the total number of educational franchise from the list. This data can be related to the fact that franchising is a good response to the financial crisis, bearing in mind that this is the safest mode of entry into entrepreneurship (Portal ideja za poduzetne, 2014). The average age of educational franchise system is 12.6 years. Positive Skewness ${ }^{1}$ value (1.647) indicates that most educational franchise began its franchise business less than 12.6 years ago. Positive Kurtosis $^{2}$ value (2.951) indicates that there are more results accumulated

\footnotetext{
${ }^{1}$ Skewness - measure of distribution asymmetry

${ }^{2}$ Kurtosis - measure of distribution homogeneity
} 
around the center of the distribution. When it comes to the total number of franchise units, the range is from 1 to 25,386 franchise units. On average, educational franchises have 469 franchise units. Positive Skewness value (8.423) indicates that most educational franchise has less than 469 franchise units, while a positive Kurtosis value (71.268) shows that there are more results accumulated around the center of the distribution. The number of international franchise units is in the range from 0 to 23,575. The average number of international franchise unit is 355 . Positive values of Skewness and Kurtosis indicate that most educational franchise has fewer than 355 international franchise units and that the results are accumulated around the center of the distribution. In a normal distribution, Skewness and Kurtosis are equal to 0 , but in the social sciences that is very rare (Table 2).

Table 2. Descriptive statistics

\begin{tabular}{lcrrrrrrrr}
\hline & $\mathrm{N}$ & Min & Max & Mean & $\begin{array}{c}\text { Std. } \\
\text { deviation }\end{array}$ & Skewness & Kurtosis \\
\hline $\begin{array}{l}\text { Number of years in } \\
\text { franchise business }\end{array}$ & 72 & 1 & 58 & 12.60 & 12,059 & 1.647 & 0.283 & 2.951 & 0.559 \\
$\begin{array}{l}\text { Total number of } \\
\text { franchise units }\end{array}$ & 72 & 1 & 25,386 & 469.36 & $2,985.117$ & 8.423 & 0.283 & 71.268 & 0.559 \\
$\begin{array}{l}\text { Number of } \\
\text { international } \\
\text { franchise units }\end{array}$ & 72 & 0 & 23,575 & 354.72 & $2,775.809$ & 8.478 & 0.283 & 71.921 & 0.559 \\
\hline \multicolumn{1}{c}{ Source: Authors' own calculations by using SPSS software } \\
\hline
\end{tabular}

Educational franchising is considered to be newer, but certainly growing industry. This is corroborated by the fact that there are five educational franchises on the Top 75 New Franchises list, on which the best franchises that started their business in the last 5 years (since 2010) are ranked. On the other hand, there are 3 educational franchises on the list Fastest Growing Franchises (102 franchises), on which the fastest growing franchises, measured by the number of newly opened franchise units in the last 2 years, are ranked (Table 3 and Table 4).

Table 3. Educational franchises on the list Top New Franchises for the year 2015

\begin{tabular}{lc}
\hline Franchise & Rank - Top New Franchises \\
\hline Engineering for Kids & 10 \\
Best in Class Education Center & 38 \\
British Swim School USA & 41 \\
Genius Kids & 43 \\
Grade Power Learning & 74 \\
\hline
\end{tabular}

Source: Adapted by the authors based on data from the Entrepreneur magazine website 
Table 4. Educational franchises on the list Fastest Growing Franchises for the year 2015

\begin{tabular}{lc}
\hline Franchise & Rank - Fastes Growing Franchise \\
\hline Mathnasium Learning Centers & 37 \\
Engineering for Kids & 78 \\
School of Rock & 85 \\
\hline Source: Adpted by the authors based on da from the Entrepreneur magazine websit
\end{tabular}

Source: Adapted by the authors based on data from the Entrepreneur magazine website

The total investment for buying the educational franchise can range from 3,500\$ in the case of Chess Math Tutoring Center, up to $4,238,875 \$$ in the case of Pinnacle Montessori. The lowest franchise fee is paid by Kumon Math \& Reading Centers franchisees $(1,000 \$)$. On the other hand, the highest franchise fee is 200,000\$, in the case of Franchise Online Trading Academy. The most of the educational franchise royalties are expressed as a percentage of gross turnover and are paid on a monthly basis, where the percentage ranges from $1.5 \%$ (Crestcom International) to $12.5 \%$ of gross turnover (FasTracKids). However, there are also educational franchises that charge their royalty in a fixed amount and it ranges from 24-29\$ per course/student per month (JEI Learning Centers), to $1,200 \$$ (Sandler Training). In the case of educational franchises, the number of years of franchise agreement duration ranges from 1 (Chess Ho Math Tutoring Center) to 20 years (Tutoring Club LLC), where the most of educational franchisees sign contracts for $5(22.22 \%)$ or 10 years (even 59.72\%). It should be noted that 7 educational franchises are on the list of Top Low-Cost Franchises (87 franchises which require less than $50,000 \$$ for business start), while 6 educational franchises are on the list Homebased/Mobile Franchises (100 franchises which can be managed from home or from a mobile unit) (Table 5 and Table 6). Therefore, we conclude that the educational franchises provide flexibility with a relatively small investment.

Table 5 Educational franchises on the list Top Low-Cost Franchises for the year 2015

\begin{tabular}{lc}
\hline Franchise & Rank - Top Low-Cost Franchises \\
\hline Club Z! In Home Tutoring Services & 19 \\
Dale Carnegie Training & 37 \\
Young Rembrandts Franchise Inc. & 47 \\
KidzArt & 49 \\
Engineering for Kids & 69 \\
Drama Kids Int'l. Inc. & 82 \\
Abrakadoodle & 87 \\
\hline Source: Adapted by the authors based on data from the Entrepreneur magazine website
\end{tabular}


Table 6. Educational franchises on the list Homebased/Mobile Franchises for the year 2015

\begin{tabular}{lc}
\hline Franchise & Rank - Homebased/Mobile Franchises \\
\hline Club Z! In Home Tutoring Services & 19 \\
Tutor Doctor & 38 \\
High Touch- High Tech & 44 \\
Dale Carnegie Training & 61 \\
Young Rembrandts Franchise Inc. & 82 \\
KidzArt & 85 \\
Zaniac & 100 \\
\hline
\end{tabular}

Source: Adapted by the authors based on data from the Entrepreneur magazine website

Despite the relatively large number of educational franchises, more than half of them still do not have their franchise units at the international market. In fact, just 29 out of 72 educational franchises have international franchise units. This means that $40.28 \%$ of educational franchises internationalize their activities through franchise units abroad, while 59.72\% still operates only at the domestic market. Correlation analysis was conducted by applying software package SPSS Statistics 20, in order to determine whether there is a positive correlation between the franchise system's age (number of years in franchise business) and the internationalization (number of international franchise units).

Table 7. Correlation analysis between the number of years in franchise business and the number of international franchise units

\begin{tabular}{lllrr}
\hline & & & $\begin{array}{c}\text { Number of } \\
\text { years in } \\
\text { franchise } \\
\text { business }\end{array}$ & $\begin{array}{c}\text { Number of } \\
\text { international } \\
\text { franchise } \\
\text { units }\end{array}$ \\
\hline $\begin{array}{l}\text { Spearman's } \\
\text { rho }\end{array}$ & $\begin{array}{l}\text { Number of } \\
\text { fears in }\end{array}$ & Correlation coefficient & 1.000 & 0.707 \\
& Sig. (2-tailed) & 72 & 0.000 \\
business & N & & 72 \\
\cline { 2 - 5 } & Number of & Correlation coefficient & 0.707 & 1.000 \\
international & Sig. (2-tailed) & 0.000 & 72 \\
\hline
\end{tabular}

Source: Authors' own calculations by using SPSS software

Based on the data given in Table 7, we can determine the direction of the relationship between the educational franchise system's age and educational franchise internationalization. Spearman's rho coefficient is positive (0.707), so we can conclude that there is a positive correlation between the number of years in franchise business and the number of international franchise units, or in other words it can be concluded that franchise systems that longer perform their franchise business intensively 
expand into the global market. We will determine the bond strength between variables in accordance with the guidelines provided by Cohen (1988, pp. 7981). We can conclude that there is a strong positive correlation between educational franchise system's age and internationalization, bearing in mind that the rho $=0.707$. The significance level $p=0.000(p<0.05)$ indicates that there is a strong and statistically significant positive correlation between these two variables. Thereby, educational franchises that longer operate in the market have a greater number of international franchise units. Therefore, we confirm the hypothesis that the educational franchise system's age, measured by total number of years in franchise business, has a positive impact on the franchise system internationalization, and that there is a strong and statistically significant positive correlation between the educational system's age and franchise system internationalization.

The results of the correlation analysis are shown in Table 8, with the aim of determining a positive correlation between franchise system's size (total number of franchise units) and internationalization (number of international franchise units).

Table 8. Correlation analysis between the total number of franchise units and the number of international franchise units

\begin{tabular}{|c|c|c|c|c|}
\hline & & & $\begin{array}{c}\text { Total number } \\
\text { of franchise } \\
\text { units }\end{array}$ & $\begin{array}{l}\text { Number of } \\
\text { international } \\
\text { franchise } \\
\text { units }\end{array}$ \\
\hline \multirow{6}{*}{$\begin{array}{l}\text { Spearman's } \\
\text { rho }\end{array}$} & \multirow{3}{*}{$\begin{array}{l}\text { Total number } \\
\text { of franchise } \\
\text { units }\end{array}$} & Correlation coefficient & 1.000 & 0.775 \\
\hline & & Sig. (2-tailed) & & 0.000 \\
\hline & & $\mathrm{N}$ & 72 & 72 \\
\hline & \multirow{3}{*}{$\begin{array}{l}\text { Number of } \\
\text { international } \\
\text { franchise units }\end{array}$} & Correlation coefficient & 0.775 & 1.000 \\
\hline & & Sig. (2-tailed) & 0.000 & . \\
\hline & & $\mathrm{N}$ & 72 & 72 \\
\hline
\end{tabular}

Source: Authors' own calculations by using SPSS software

The data shown in Table 8 indicate that there is a positive correlation between the educational franchise system's size and the educational franchise internationalization. Spearman's rho coefficient is positive (rho=0.775), so it can be concluded that there is a strong positive correlation between the total number of franchise units and the number of international franchise units, or in other words that larger franchise systems intensively expand their franchise business in the global marketplace. The significance level $p=0.000$ $(\mathrm{p}<0.05)$ indicates that there is strong and statistically significant positive correlation between these two variables. Thereby, larger educational franchises have a greater number of international franchise units. Thus, we confirm the hypothesis that educational franchise system's size, measured by the number of franchise units, has a positive impact on the franchise system 
internationalization, ie. there is a strong and statistically significant positive correlation between the educational franchise system's size and the internationalization.

Educational franchises in the sector of non-formal education that are ranked on Entrepreneur magazine's website can be classified into 7 categories (fields): tutoring, art classes, childcare, supplemental education, sport training, training, science, technology, engineering and math classes. The largest number of educational franchises are in the field of science, technology, engineering and math classes (15 franchises, or 20.83\%), tutoring (14 franchises, or 19.44\%), supplemental education (13 franchises, or $18.06 \%$ ), art classes (11 franchises, or $15.28 \%$ ), childcare (10 franchises, or $13.89 \%$ ), training ( 7 franchises, or $9.72 \%$ ), while the smallest number of franchises are in the field of sport training ( 2 franchises, or $2.78 \%$ ). In the field of art classes, 6 out of 11 franchises operate in the international market, or more than half $(54.54 \%)$. When it comes to educational franchises in the area of childcare, there are still no franchises that operate in the global market. In the field of science, technology, engineering and math classes, 6 out of 15 franchises have international franchise units, or $40 \%$. In the field of supplemental education 7 out of 13 franchises have global presence, ie. $53.85 \%$. In the field of sport training, all franchises have presence on the international market. When it comes to franchises in the field of training, 4 out of 7 franchises have franchise units on international level, ie. 57.14\%. In the area of tutoring, only 4 out of 14 franchises have global presence, or $28.57 \%$. Kruskal-Wallis test is used in order to determine whether there is a difference between educational franchise systems from various areas of providing educational services and the internationalization. It is necessary to consider the value of Chi-Square indicator, the number of degrees of freedom (df), and significance level (Asymp. Sig.). In this case, the level of significance is less than 0.05 and amounts to 0.035 , so the difference in the obtained values of continuous variable (the number of international franchise units) among the 7 above mentioned categories is statistically significant. This confirms the hypothesis that educational franchise system's area of providing educational services has an impact on the franchise system internationalization, ie. there is a difference between the educational franchise systems from various areas of providing educational services and the internationalization. By examining the Mean Rank, it can be determined from which areas of providing educational services are educational franchises with the largest number of international franchise units. The conclusion is that educational franchises from the area of sport training have the largest number of international franchise units, considering that mean rank is 53.50. On the other hand, educational franchises from the area of childcare have the smallest number of international franchise units, bearing in mind that mean rank is 22.00 (Table 9). However, the results should be observe in the light of the fact that there is a large disparity in the number of educational 
franchises in certain areas (for example, the smallest number of educational franchises is in the field of sports training - only two), which has an impact on obtained results, with regard to the value of Mean Rank and, consequently, on conclusions regarding the internationalization of franchises from certain areas.

Table 9. Kruskal-Wallis Test

\begin{tabular}{|c|c|c|c|}
\hline & Field & $\mathrm{N}$ & Mean Rank \\
\hline Number of & Tutoring & 14 & 30.57 \\
\hline international & Art classes & 11 & 41.18 \\
\hline \multirow[t]{7}{*}{ franchise units } & Childcare & 10 & 22.00 \\
\hline & Supplemental education & 13 & 44.81 \\
\hline & Sport training & 2 & 53.50 \\
\hline & Training & 7 & 43.64 \\
\hline & $\begin{array}{l}\text { Science, technology, engineering and } \\
\text { math classes }\end{array}$ & 15 & 35.47 \\
\hline & Total & 72 & \\
\hline & Number of international franchise units & & \\
\hline Chi-Square & 13.588 & & \\
\hline Df & 6 & & \\
\hline Asymp. Sig. & 0.035 & & \\
\hline
\end{tabular}

\section{CONCLUSION}

Educational franchises have become a global phenomenon, especially in terms of the increasingly intensive internationalization of education. Educational franchise sector, with annual revenue of 40 billion US\$ and expected growth of $5 \%$ per year over the next 5 years, represents an excellent opportunity to start a business with not only the achievement of profit goals, but also social goals, such as the spread of knowledge. Franchising in education occurs most often in the form of academic franchise (in the sector of formal education) and non-academic franchise (in the sector of non-formal education).

The paper analyzes the educational franchises that are ranked on Entrepreneur magazine's website for the year 2015. Based on the conducted statistical analysis, the paper points out the impact of internal factors from the domain of franchise system's size, age and area of providing educational services on the internationalization. Correlation analysis indicated that there is strong and statistically significant positive correlation between educational franchise system's size (total number of franchise units) and internationalization (number of international franchise units) as well as strong and statistically significant positive correlation between educational franchise system's age (number of years in franchise business) and internationalization. In addition, Kruskal-Wallis test indicated that franchise 
system's area of providing educational services has an impact on the educational franchise system internationalization, ie. there is a difference between educational franchise systems from various areas of providing educational services and the internationalization.

The results of the conducted research are consistent with results of previous studies which have shown that size and age of franchise system have a positive impact on internationalization, since larger and older franchise systems have more resources for international expansion (Aydin \& Kacker, 1990), better international performance (Wagner, 2001; Harris \& Li, 2009), better monitoring capabilities (Huszagh et al., 1992) and higher capacity to absorb risk and failure (Eroglu, 1992). Further research should be directed to the analysis of the impact of external factors on the educational franchise system's internationalization and the analysis of the international dimension in terms of franchisees. Also, further studies should be focused on internationalization of academic franchises, ie. franchises in the sector of formal education. A key limitation of this study is the fact that the educational franchising is still in development, and that there is a lack of available literature and studies on this topic.

\section{REFERENCES}

Adams, J. N., Prichard Jones, K. V. (1990). Franchising: practice and precedents in business format franchising. London: Butterworths

Altbach, P. G. (2002). Knowledge and education as international commodities: The collapse of the common good. International Higher Education, 28, 2-5.

Altbach, P.G. (2012). Franchising -The McDonaldization of Higher Education. International Higher Education. 66, 7-8.

Aurini, J. (2006). Crafting Legitimation Projects: An Institutional Analysis of Private Education Businesses. Sociological Forum, 21(1), 83-111.

Aurini, J., Davies, S. (2004). The Transformation of Private Tutoring: Education in a Franchise Form. Canadian Journal of Sociology, 29(3), 419-438.

Aydin, N., Kacker, M. (1990). International outlook of U.S.-based franchisers. International Marketing Review, 7(2), 43-53.

Baker, D.P., Akiba, M., Le Tendre, G.K., Wiseman, A.W. (2001). Worldwide Shadow Education: Outside-School Learning, Institutional Quality of Schooling, and Cross-National Mathematics Achievement. Educational Evaluation and Policy Analysis, 23, 1-17.

Bray, M. (1999). The Shadow Education System: Private Tutoring and its Implications for Planners. Paris: International Institute for Educational Planning.

Bray, M., Lykins, C. (2012). Shadow Education Private Supplementary Tutoring and Its Implications for Policy Makers in Asia, Asian Development Bank

Cohen, J.W. (1988). Statistical power analysis for the behavioral sciences. Hillsdale, NJ: Lawrence Erlbaum Associates.

Davies, S., Aurini J., Quirke, L. (2002). New Markets for Private Education in Canada. Education Canada, 42(3), 36-41.

Entrepreneur (2015). 2015 Franchise 500 Ranking, Retrived from: https://www. entrepreneur.com/franchise500/2015/1 (01.11.2017.) 
Eroglu, S. (1992). The Internationalizing process of franchise system: A conceptual model. International Marketing Review, 9(5), 19-30.

European Commission (2011). The challenge of shadow education. Private tutoring and its implications for policy makers in the European Union. An independent report prepared for the European Commission by the NESSE network of experts, NESSE.

Franchise help (2016). Education franchises, Retrieved from: https://www.franchisehelp. com/industry/education-franchise (28.12.2016.)

Harris, R., Li, Q. C. (2009). Exporting, R\&D, and absorptive capacity in UK establishments. Oxford Economic Papers, 61, 74-103.

Herman, G. (2004). New Directions in Internationalizing Higher Education: Australia's Development as an Exporter of Higher Education Services. Higher Education Policy, 17, 101-120.

Hira, A. (2003). The brave new world of international education. The World Economy, 26(6), 911-931.

Huszagh, S.M., Huszagh, F.W., Mclntyre, F. (1992). International franchising in the context of competitive strategy and the theory of the firm. International Marketing Review, 9(5), 5-18.

Lareau, A. (2002). Invisible Inequality: Social Class and Childrearing in Black and White Families. American Sociological Review, 6, 747-776.

Mori, I., Baker, D. (2010). The Origin of Universal Shadow Education: What the Supplemental Education Phenomenon tells us about the Postmodern Institution of Education. Asia Pacific Education Review, 11(1), 36-48.

Murawska, B., Putkiewicz, E. (2006). 'Poland', in Silova, Iveta; Būdienė, Virginija \& Bray, Mark (eds.), Education in a Hidden Marketplace: Monitoring of Private Tutoring. New York: Open Society Institute, 257-277.

OnHand Schools (2016). What is a learning center? How can I create one in my classroom?, Retrieved from: https://onhandschools.wikispaces.com/file/view/ learning+center+definition+and+how+to.pdf (28.12.2016.)

Portal ideja za poduzetne (2014). Abeceda franšizinga [The ABC of Franchising], Retrieved from: http://franchising.hr/clanak/586/abeceda-fransizinga (28. 12. 2016)

Southgate, D.E. (2009). Determinants of Shadow Education: A Cross-National Analysis. Dissertation Presented in Partial Fulfillment of the Requirements for the Degree Doctor of Philosophy. Graduate School of The Ohio State University

Stevenson, D.L., Baker, D.P. (1992). Shadow education and allocation in formal schooling: Transition to university in Japan. American Journal of Sociology, 97(6), 1639-1657.

Wagner, J. (2001). A note on the firm size - export relationship. Small Business Economics, 17(4), 229-237.

Yorke, M. (1993). Quality Assurance for Higher Education Franchising. Higher Education, 26(2), 167-182. 


\title{
ЕДУКАТИВНИ ФРАНШИЗИНГ КАО СТРАТЕГИЈА ИНТЕРНАЦИОНАЛИЗАЦИЈЕ ОБРАЗОВАЫА
}

\author{
Сузана Стефановић ${ }^{1}$, Милица Станковић ${ }^{2}$ \\ ${ }^{1}$ Универзитет у Нишу, Економски факултет, Ниш, Србија \\ ${ }^{2}$ Висока школа примењених струковних студија, Врање, Србија
}

\begin{abstract}
Резиме
Сектор едукативног франшизинга, са годишњим приходом од 40 милијарди долара и очекивањима за раст по стопи од $5 \%$ годишње у наредних 5 година, представља одличну прилику за отпочињање пословања уз остварење циља који није само оријентисан на профит већ и на друштвене циљеве, попут ширења знања. Едукативне франшизе постају глобални феномен, имајући у виду да обезбеђују стандардизоване едукативне програме који се могу прилагодити локалним студентима који стичу упоредиво, али не нужно идентично знање. Циљ рада је да се укаже на значај едукативног франшизинга и његову улогу у интернационализацији образовања. Аутори анализирају едукативне франшизе, са посебним освртом на едукативне франшизе у сектору неформалног образовања. Едукативне франшизе у сектору неформалног образовања најчешће се јављају у форми „образовања из сенке” и „центара за учење”, те се у раду указује на карактеристике и разлике између ове две форме едукативних франшиза.

Емпиријско истраживање је спроведено коришћењем секундарних података о едукативним франшизама које се рангирају на сајту магазина „Entrepreneur”. На листи магазина „Entrepreneur” за 2015. годину налазе се чак 72 франшизе из области образовања, што указује на значај едукативних франшиза на глобалном нивоу. Анализа резултата емпиријског истраживања спроведена је применом статистичких техника, коришћењем софтверског пакета SPSS Statistics 20. Статистичке технике које су коришћене у раду су корелациона анализа и Kruskal Wallis тест. Корелациона анализа је показала да постоји јака и статистички значајна позитивна корелациона веза између величине едукативних франшизних система (односно укупног броја франшизних јединица) и интернационализације (посматрано кроз број интернационалних франшизних јединица), као и јака и статистички значајна позитивна корелација између старости едукативних франшизних система (односно броја година франшизног пословања) и интернационализације. Поред наведеног, Kruskal Wallis тест је показао да област пружања услуга едукативних франшиза утиче на интернационализацију њихове активности, односно да се едукативне франшизе из одређених области више интернационализују у односу на друге. На основу свеобухватне статистичке анализе, потврђене су полазне хипотезе да унутрашњи фактори из домена величине, старости и области пружања услуга едукативног франшизног система утичу на интернационализацију франшизне мреже.
\end{abstract}

